\title{
A SWOT Analysis of Nepalese Hydropower Policy
}

\author{
Birendra Rana \\ University of Nevada Reno, Reno, NV, 89503 USA \\ * Corresponding author email: birendraja@gmail.com \\ Received: 04 July 2020 / Revised: 19 July 2020 / Accepted: 21 July 2020 / Published: 24 July 2020
}

\begin{abstract}
Hydropower, in which Nepal has comparative advantage, has a potential to contribute to Nepal's energy security and sustainable development. The government of Nepal enacted the Hydropower Development Policy in 2001 (HDP-2001) as an overarching policy to coordinate all policies forthcoming in this sector. This paper has critically analysed HDP-2001 by applying the Ecosystem services-based Strength, Weakness, Opportunity, and Threat (SWOT) technique. The paper has evaluated peer-reviewed scholarly articles, secondary data, and government publications available in public domain. The strengths and weaknesses of the policy were analysed by applying seven specific indicators. The research indicates that HDP-2001 has been successful in overcoming some of the pertinent challenges in Nepalese hydroelectric industry, however it also faces several limitations on account of climate change, economic dislocations, effective monitoring, ensuring competitiveness, delivering fair price to the consumers, and institutional governance issues. Designing a practical mitigation plan, while being aware of its limitations, could be helpful in minimizing the impact of these exogenous factors.
\end{abstract}

Keywords: Ecosystem services-based SWOT, Hydropower Policy, Nepal

\section{Introduction}

Nepal is a small, Himalayan country tucked between China and India. It is a landlocked mountainous country, with an area of 147,181 square kilometres and the population approaching to 30 million (Central Bureau of Statistics, 2015; Worldometer, 2020). Nepal's geography has three distinct features viz. northern mountains, middle hills, and southern terai plain (35\%, 42\%, and 23\% respectively), and the topography of the country with hundreds of high gradient rivers originating from the Himalayan mountains is highly conducive for construction of run-of-river hydropower projects (Alam, et al., 2017). It is estimated that Nepal has a hydropower potential of 84,000 MW, of which the feasible potential is only about 46,000 MW (Zhou, 2011). Thus, Nepal has a comparative advantage in hydropower. However, the progress in this sector had been slow because the government had held absolute monopoly in hydropower project construction, transmission, and distribution of electricity in the country until 1991 (Poudyal, Loskot, Nepal, Parajuli, \& Khadka, 2019). It was only towards the end of twentieth century that the government started gradually opening the energy sector to private investors in an effort to encourage private capital and managerial skills. Since then, there has been a significant increase in the investment amount as well as the number of hydropower projects constructed in the country that are developed along the Build, Own, Operate, and Transfer (BOOT) mechanism.

The Department of Electricity Development under the Ministry of Energy, Water Resources \& Irrigation, Government of Nepal keeps a repository of all hydropower projects that have obtained survey license, generation license, or have already started commercial operation. As of June 30, 2020, there were 85 hydropower projects in operation with a total installed capacity of 1,120.469 MW and 226 projects under construction with an aggregate capacity of 7,956.661 MW (Nepal Electricity Authority, 2019.). Thus, the average capacity of hydropower projects in operation is $13.18 \mathrm{MW}$, and that of a project under construction is $35.20 \mathrm{MW}$. Thus, Nepal has been prioritizing construction of small and medium-sized hydropower 
A SWOT Analysis of Nepalese Hydropower Policy

projects (Balasubramanya, Giordano, Wichelns, \& Sherpa, 2014). Today hydropower contributes more than 90 percent of the total electricity produced of the country (IHA, 2020) and it provides employment opportunities to thousands of semi-skilled labourers in the country. Therefore, this sector has a potential to contribute to the economic growth and development of Nepal through low carbon energy transition (Shakya, Nepal, \& Sharma, 2018). However, after the deregulation in the hydropower sector, some confusion persisted among the hydropower developers, government agencies, funding institutions and local governments, although the government issued singular directives on ad-hoc basis from time to time.

A need was therefore felt by all stakeholders in the hydropower sector of Nepal to have an overarching policy guideline that would integrate the existing policies and provide a solid groundwork for all forthcoming sectoral policies. In that direction, the government of Nepal formulated the "Hydropower Development Policy," (HDP-2001) that was in the aftermath of the World Commission on Dams 2000 report and the commitments of Millennium Development Goal (United Nations Millennium Development Goals, n.d.) (Wang X. , 2017). This paper seeks to examine the HDP-2001 in the framework of "Ecosystem services-based Strength, Weakness, Opportunity and Threats (SWOT) Analysis".

\section{Literature Review}

Energy is a crucial component required for economic development; in fact, a country's living standard is evaluated based on its energy consumption per capita. Hydropower can be a potential source for clean, renewable energy with several upsides to tackle climate change. Although hydropower development is a controversial topic (Ansar, Flyvbjerg, Budzier, \& Lunn, 2014), it has been associated with promoting rural economic development and poverty alleviation in many countries, including in Nepal (Gunatilake et al, 2020). A hydropower policy is therefore meant to support the present and future energy requirements of a country by developing hydropower projects. With its growing population and rapid urbanization, the demand of electricity in Nepal is bound to increase significantly. According to the estimates by Nepal Electricity Authority, the electricity demand is expected to spike from 10,138 gigawatt-hours in 2019-2020 to $31,196 \mathrm{GWh}$ in 2029-2030 (NEA, 2019). And since Nepal meets more than $90 \%$ of its electricity needs from hydropower (IHA, 2020), a SWOT analysis of its hydropower development policy is crucial for its energy security. This study will not undertake the SWOT analysis of the energy sector in Nepal, but it rather focuses on the its hydropower development policy.

SWOT analysis of public policy is a relatively new concept. The SWOT analysis has traditionally been performed as part of the broader planning strategy by businesses or planners (Fertel, Bahn, Vaillancourt, \& Waaub, 2013) that afforded them more insight into how to reinforce the strengths and utilize the potential opportunities, and how to tackle the weaknesses and potential threats. For instance, many European countries have utilized the SWOT analysis in their planning and policies making (European commission, 2004). While there are instances of energy policies being evaluated using Multicriteria Decision Analysis approach such as in case of Vietnam's low-carbon energy policy (Shem, Simsek, Hutfilter, \& Urmee, 2019), there are few studies that have used SWOT analysis in energy policy arena. A SWOT analysis of Poland's renewable energy sector (Igliński, Piechota, Iglińska, Cichosz, \& Buczkowski, 2016) recommended the need for legal reforms, access to finance, and supportive market prices, however the study used the energy policy and energy sector interchangeably. Ifran et al (2019) carried out the SWOT analysis of the energy policy of Pakistan based on three themes viz. "efficiency, competition, and sustainability" (Irfan, Suleman, Sarwar, Abas, \& Saleem, 2019). They concluded that Pakistan's energy policy suffered from several weaknesses including the widening supply-demand gap, high cost of electricity generation, transmission losses, distribution loss, less diversified energy mix, and electricity theft. However, they are silent on impact of climate change, cross sectoral impediments, and the issue of cooperation between regional and central administration, etc which are some real concerns. Likewise, a SWOT analysis of energy policies of China, Japan, and Korea, they found that there are plenty of opportunities to collaborate between them in the space of clean energy (Chen, Kim, \& Yamaguchi, 2014), however the political relationship between them remains the biggest risk. Likewise, the SWOT analysis of Ghana's nuclear power energy policy (Agyekum, 
Birendra Rana, Adv. J Social Sci.; Vol. 7, Issue 1, pp: 71-80, 2020

Ansah, \& Afornu, 2020) identifies the financing models for the construction as the biggest challenge, however it does not acknowledge the institutional reforms and technological constraints as barriers.

All the above studies focused on improving energy mix, increasing share of renewable energy in their energy mix, and providing a fair price to the end consumer, however, they did not use a common methodology for their analyses. It is relevant to review the current hydropower development policy, so that government can make necessary adjustments to strengthen the energy security of the country, which is one of the goals of the Sustainable Development Goals 2030. In case of Nepal's HDP-2001, there have not been any formal attempts to review the policy using SWOT technique to examine the strengths, weaknesses, opportunities, and threats associated with this policy since its formulation. The primary objective of this study therefore is to assess the strengths and observed weaknesses of the HDP-2001, and to evaluate the opportunities and potential threats of the HDP - 2001. More concretely, the study seeks to evaluate the multidimensional factors that influence the outcome of the Hydropower Development Policy 2001, and to identify plausible gaps and barriers areas where there is an opportunity for improvement.

\section{Methods}

A SWOT analysis presents a visual matrix to provide insights and strategic management tool to a business entity based on its market positioning and unique-selling points (Helms \& Nixon, 2010). However, the SWOT analysis has also been extended significantly and successfully applied to other disciplines too (Igliński, Piechota, Iglińska, Cichosz, \& Buczkowski, 2016). Ecosystem services-based SWOT analysis that was first used by Scolozzi et al (2014) in connection with protected areas of conservation is applied here to devise a framework that distinguishes the HDP-2001 into endogenous and exogeneous factors influencing its outcome (Scolozzi, Schirpke, Morri, D'Amato, \& Santolini, 2014). Some studies have extended this approach to policy arena (Gc \& Ghimire, 2018). Extending this debate in hydropower sector, the strength and weaknesses are classified as endogenous factors, while the opportunities and threats fall under exogeneous factors. The details of each of these factors is described in Table 1 below:

Table 1: An interdisciplinary interpretation of dynamics between SWOT elements

\begin{tabular}{|c|c|c|c|}
\hline & & Business/ Management & Policy Perspective \\
\hline \multirow{2}{*}{ 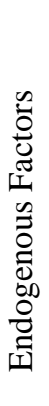 } & 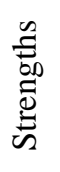 & $\begin{array}{l}\text { Characteristics of the business/ the } \\
\text { project to stay ahead of the game. }\end{array}$ & $\begin{array}{l}\text { Both the Characteristics and policy options provide } \\
\text { an advantage. The policy options address both the } \\
\text { current and upcoming problems }\end{array}$ \\
\hline & 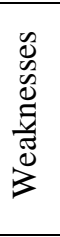 & $\begin{array}{l}\text { Characteristics that are a } \\
\text { disadvantage for the business/ } \\
\text { project. }\end{array}$ & $\begin{array}{l}\text { Characteristics which are a disadvantage for the } \\
\text { policy. The policy options that cannot address the } \\
\text { existing and upcoming issues. Similarly, such } \\
\text { options have a negative impact on the success of the } \\
\text { policy. }\end{array}$ \\
\hline \multirow{2}{*}{ 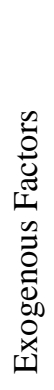 } & 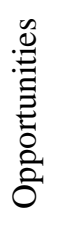 & $\begin{array}{l}\text { Elements that the project can } \\
\text { exploit to its advantage }\end{array}$ & $\begin{array}{l}\text { Exogenous factors which will be beneficial for the } \\
\text { success of the policy if carefully grasped. }\end{array}$ \\
\hline & $\stackrel{\mathscr{E}}{\stackrel{\mathscr{E}}{E}}$ & $\begin{array}{l}\text { Elements in the environment that can } \\
\text { potentially jeopardize the } \\
\text { business/project }\end{array}$ & $\begin{array}{l}\text { Exogenous factors which will pose a risk to the } \\
\text { failure of the policy and cannot be controlled by the } \\
\text { policy itself. }\end{array}$ \\
\hline
\end{tabular}




\section{Discussion}

For a comprehensive review and analysis of the strengths and weaknesses of HDP-2001, they were categorized under seven different characteristics, viz. "Broader Objective", "Inclusive Development", "Competition and Collaboration", "Innovation", "Sustainability \& Environment", "Effective Monitoring" and "Policy Outreach" for an objective comparison. This exercise enables us to gain a better understanding of an issue within a category from the strength and weakness perspectives. A policy has a broader implication, each subset under the strengths category will likely have a contrarian element in the weaknesses category, and different elements can have a juxtaposition of both strengths and weaknesses allowing for partial integration of attitudes, norms, or patterns of culture across time and space. The results of the study are presented subsequently into four distinct subheadings namely Strengths, Weaknesses, Opportunities and Threats.

\subsection{Strengths}

(1) Broader Objective: Upon close review of the HDP-2001, we can categorize its policy objectives into three distinct parts as related to the hydropower developers, consumers, and broader society. The objectives that are linked to the hydropower developers are geared towards increasing both the generation of hydroelectricity and distribution capacity of transmission infrastructure in the country, as well as increasing the prospects of export to neighboring countries through the development of cross-border transmission grid system. Likewise, the policy objective linked to the broader society is a reflection of the sustainability concerns in the aftermath of World Commission of Dams 2000 report because it seeks to develop the natural resources, while preserving the environment and biodiversity (p. 81). In view of this policy objective, the HDP-2001 has done a good job in addressing issues related to the hydropower producers and broader society however it falls short of satisfying the consumers' concern about getting a fairer price. Nonetheless, this policy is geared towards enhancing the hydropower generation capacity \& reliability of electricity supply, improving the energy security at low cost, and ensuring better distribution capacity that are linked to consumers' issues at the policy levels, instead of as a disconnected goal.

(2) Inclusive Development: The HDP-2001 has a section (section 6.4) that underscores Rural Electrification, a concept that has been prioritized for infrastructure development by the Government of Nepal. In addition, the policy stipulates that "the energy royalty on the electric energy consumed in such a rural area shall be exempted for the initial 15 years of the successful commissioning of the project" (section 6.4.3). Furthermore, "one per cent of the royalty obtained by Government of Nepal from a hydropower project is to be allocated to the Village Development Committees that are impacted by the project development activities" (section 6.4.4). Such measures were arguably envisaged for the focus group or rural population by the government of Nepal, and these policy measures are also aligned with the spirit of hydropower benefit sharing with local people (Wang C. , 2012). Thus, the objective of supporting rural economic development by extending rural electrification is essentially a bottom-up participative mechanism that has been embraced to increase the inclusiveness of HDP-2001.

(3) Competition and Collaboration: Another objective of the HDP-2001 is aimed at increasing the commercialization and competitiveness of the hydropower industry in Nepal. To generate electricity at lowest cost by utilizing the water resources available in the country seems to be the primary focus of this policy. Private sector plays an important role considering high upfront costs and technical expertise required for hydropower projects, economies of scale. The policy has provisions for appropriate incentive measures and transparent process to attract national and foreign investment in hydropower development. 
Birendra Rana, Adv. J Social Sci.; Vol. 7, Issue 1, pp: 71-80, 2020

The HDP-2001 emphasizes the collaboration and strategic partnership between the government agencies, private enterprises, civil groups, and regional governments within Nepal. Cooperation with South Asian countries is another strength of the HDP-2001 because it tremendously helped steer a strategy of bilateral and regional collaboration in the hydropower sector in view of fact that tremendous potential of feasible hydropower in Nepal could match the growing demand of electricity in neighboring India and Bangladesh. Thus, the hydropower development of Nepal supports its domestic economy and the regional economies (Suhardiman \& Karki, 2019).

(4) Innovation: Increasing electricity generation and efficiency of distribution has been a major hurdle in Nepal since it required significant capital investment in infrastructure in rural and hilly terrains such as transmission lines, rural access roads, communication links, and market mechanism (Shrestha, Biggs, Justice, \& Gurung, 2018). Thus, the assurance of improved inputs, increased investment and better technologies have been proposed for modernization. The introduction of project financing mechanism justified by future cashflows of the PPA-backed projects and insurance of loss of profits and revenues due to environmental disaster is another strength of the HDP-2001 for the modernization of Nepalese hydropower sector. The HDP-2001 has encompassed innovative quality controls, better regulatory interface, and an integrated market for modernization.

(5) Sustainability and Environment: The HDP-2001 emphasizes "hydropower development focusing on national interest, environment protection and maximizing benefits in the development of water resources of Nepal" (section 6.1). This leads to environment impact assessment studies for hydropower development to govern the environmental-related matters during the construction of hydropower project infrastructures such as powerhouses, dam sites, tunnels, canals, reservoirs, transmission lines, and distribution lines. Some policies, such as discouraging Furthermore, the commitment to release at least ten percent of the minimum monthly average discharge of the river and protection of biodiversity are the other strengths of the HDP-2001. With respect to the climate change induced threats that can jeopardize the sustainability of hydropower in Nepal, this regulation is a robust policy measure to mitigate such practices (Pathak, 2011).

(6) Effective Monitoring: A pragmatic monitoring system that underscores various stakeholders is a strength of the HDP-2001. The stipulated provision of encouraging multi-level committees that would have oversight on activities related to participatory and coordinative program is highly encouraging. Moreover, the guideline on licensing, planning, implementation, and monitoring of hydropower projects rendered the HDP-2001 structurally robust.

(7) Policy Outreach: In addition to the above stated strengths of the HDP-2001, it was successful in projecting itself as the unified fundamental national policy for development of hydropower sector in Nepal by bringing together several scattered pieces of guidelines under one umbrella. It provided better clarity on the issues that were badly needed in the industry. It was a timely policy that acknowledged the strategic importance of developing hydropower in the country, and also provide consistency to the policy of government of Nepal in this sector.

\subsection{Weaknesses}

(1) Broader Objective: The policy objective with respect to the consumers is seriously lacking in the HDP-2001. The explanation of "favorable consumer price" is not clearly specified in the HDP2001. Apropos the fact that government has tremendous leverage on designing a policy that influences the quality service to the retail consumers, there is definitely a merit in the argument for a need to improve overall competency, motivation, and professionalism to serve the needs of consumers at large (Sen, Nepal, \& Jamasb, 2018). These deserving issues were unfortunately not 
A SWOT Analysis of Nepalese Hydropower Policy

prioritized by the HDP-2001. Moreover, the issue of improving quality of governance which is a critical element in rendering better output was not envisioned in the HDP-2001.

(2) Inclusive Development: Although HDP-2001 envisioned the idea of an inclusive development beyond the borders of urban centers, it lacked a guideline or implementation mechanism for accomplishing the broader vision of "rural poverty reduction", which is a determining factor for inclusive growth and development (Pulice, Branco, Gallardo, Roquetti, \& Moretto, 2019). For instance, failure to adopt the concept of the Local Benefit Sharing Mechanism of hydropower projects, which was the most significant recommendation of the World Commission of Dams 2000 report, was a missed opportunity. Similarly, promotion of local off-line grid network could be a better option for rural electrification and development in Nepal.

(3) Competition and Collaboration: Notwithstanding the fact that HDP-2001 was principally supportive of the idea of healthy competition in hydropower sector, the policy as a whole was unsuccessful in realizing global players into the competition. Although Nepal presented an attractive option for global investors due to its geographical diversity, the Nepalese hydropower sector suffers from high transaction costs (Nepal \& Paija, 2019) and transparency issues which the HDP-2001 failed to overcome. Furthermore, the domestic demand in Nepal is still low. As a result, the government is exploring export opportunities to the regional market particularly to India and Bangladesh. However, lack of cross-border transmission infrastructure facilities and coordination at diplomatic levels with India have been some key bottlenecks.

As a matter of fact, Nepal cannot consume all the electricity generated from the projects under construction, and hence one can reasonably argue that the HDP-2001 failed to foresee this strategic point. And although the HDP-2001 underscored cooperation among several government agencies within the country, there are still confusions and differences in departmental differences on the roles of federal agencies such as Department of Electricity Development, Department of Forest, Nepal Electricity Authority, state governments, and the local district administration which leads to confusion and contradiction on implementation. For instance, there is lack of convergence on departmental regulations with respect to land procurement and removing trees during hydropower construction.

(4) Innovation: While HDP-2001 embraced the notion of modernization as a guiding principle to provide quality electricity service to the end consumers, it was not successful in explaining how it would ensure its successful implementation. The connection between cost of hydropower projects and pricing of electricity market was not clear. Most electricity producers suffer from a host of natural and manmade challenges, thereby suffering from losses and consumers paying the same price for electricity. Similarly, cutting down the transmission and distribution losses, which is a critical aspect of modernization, was not considered sufficiently. The project financing for hydropower projects was not adequately discussed in the policy, and consequently the government introduced a separate policy (Sovacool, Dhakal, Gippner, \& Bambawale, 2013). However, the use of ambiguous terms such as "appropriate government support" (p. 55) and "adequate compensation" (p. 71) creates challenges during implementation.

(4) Sustainability and Environment: While the government has categorized hydropower projects as sustainable energy projects, many scholars have argued against the framing of hydropower as a "green energy" (Kibler \& Tullos, 2013) because of its deleterious impact on environment, biodiversity, and aquatic life. Moreover, if Nepal is not able to export its electricity to neighboring countries and if the domestic demand remains diminished, the likelihood of surplus electricity generation will create a situation where more hydropower generation would not seem like a sound policy. 
Birendra Rana, Adv. J Social Sci.; Vol. 7, Issue 1, pp: 71-80, 2020

(6) Effective Monitoring: Nepal Electricity Authority, the national off-taker of electricity, is engaged in generation, transmission, and distribution of electricity in Nepal. And its involvement in policy formulation, implementation, and monitoring essentially weakens the fundamental principle of independent monitoring. Moreover, no timeline is given for establishment for Electricity Regulation Commission, which is crucial for overseeing the policy related aspects in energy sector in Nepal, which is seriously lacking. There is also confusion on monitoring mechanism to ensure the appropriate levels of environmental flows by a hydropower project. Therefore, effective monitoring is one of the weak spots of the HDP-2001.

(7) Policy Outreach: The HDP-2001 has undoubtedly been a unified guideline of policies for the Nepalese hydropower sector, and there are plenty of good points about it as highlighted in the previous sub-section. Nonetheless, there were numerous policies that were enacted before it, such as the Hydropower Development Policy 1992, Electricity Act 1992, Electricity Regulations 1993 etc. And it was not particularly effective in explaining the status or integrating these policies that were enacted before it thereby creating confusion.

\subsection{Opportunities}

In the previous two sub-sections, we discussed the various endogenous factors that could strengthen or potentially weaken the policy objectives of HDP-2001. Now, we will discuss some exogeneous factors which could result build towards the success or failure of the HDP-2001. The following are these potential factors:

(1) First and foremost, the growing population of Nepal, rapid urbanization, change in people's lifestyle, and diversification of use of electricity from merely lighting to heating, cooking, transportation, and others should strongly increase the domestic consumption of electricity. Hence, it is a robust exogenous factor supporting the objectives of HDP-2001.

(2) The growing interest of private sector and foreign investors in Nepalese hydropower sector creates a conducive environment for hydropower development. Investment Board of Nepal, Dolma Impact Fund, and FMO Netherlands, etc have played instrumental role in attracting private equity from international market. Similarly, financiers, issue managers, entrepreneurs and traders are organizing gradually (Neupane, 2014). Increasing government-to-government cooperation is a positive exogenous factor that would create a favorable environment towards success of the HDP2001.

(3) In almost every annual budget and economic white paper, the government seems to identify development of hydropower as the topmost priority. Nevertheless, the government's declared support such as the tax rebates, tariff revision, and other incentives to independent power producers have not been delivered in a timely manner to accomplish the anticipated growth and to ensure energy security. Furthermore, revolution in Information Communication Technologies (ICTs) including Artificial Intelligence, and Cloud Computing is another opportunity that could contribute towards greater success of the HDP-2001.

(4) Nepal has been experiencing a significant growth in foreign remittance (Kaphle, 2019), and there is an opportunity to incorporate this resource in a productive way to benefit the hydropower sector. Likewise, issuance of green bonds and establishment of energy focused institutions such as Hydropower Investment Development Co. Ltd and Infrastructure Bank Ltd are some factors that will potentially reinforce the success of HDP-2001.

(5) Small hydropower projects are generally considered more sustainable (Lange, et al., 2018), which is a positive factor that supports. Growing concern over "energy security", especially in the wake 
A SWOT Analysis of Nepalese Hydropower Policy

of Sustainable Development Goals 2030 (Halisçelik \& Soytaş, 2019), has potential to contribute positively towards the success of the HDP-2001.

\subsection{Threats}

Notwithstanding the potential opportunities as discussed above, there are some serious setbacks and policy constraints of the HDP-2001 that could potentially jeopardize its successful implementation and hence accomplishment of its objectives.

(1) Climate Change and climate induced factors such as GLOF, Earthquakes, landslides, etc. pose a real threat to the development of sustainable hydropower and eventually to the achievement of HDP-2001 objectives. Nepalese hydropower is therefore highly dependent on stable climate conditions. Unfortunately, climate change, which is a serious exogenous factor, was not given due consideration in the HDP-2001 even though there are also plenty of documentation that underscore the impact of climate change on sustainability of hydropower projects (Carvajal, Anandarajah, Mulugetta, \& Dessens, 2017).

(2) Geopolitical situation: Being a landlocked country, Nepal looks forward to the unrestricted supply of inputs and access to regional energy market for achieving the desired pace of growth in hydropower sector. Unfortunately, the trade relations between regional countries in South Asia are contingent on political relationship between them, and Nepal has encountered several trade supply restrictions in past along its southern border that has adversely affected development of this sector (Haque, Dhakal, \& Mostafa, 2019). Moreover, the electricity protectionist policies such as heavy subsidies of the neighboring countries could hinder the export of Nepalese hydropower export and eventually threaten the HDP-2001 objectives.

(3) External shocks such as global recession 2008, earthquake 2015, COVID-19 epidemic etc. can cause severe market dislocations. These events not only reduce the flow of capital, but also restrict movement of manpower and labor from southern plains of Nepal and India.

(4) Policy discrepancy is a matter of concern apropos the success of the HDP-2001. Ironically, the existing import policies in Nepal favor reduced tariffs on fabricated rolled pipes used in hydromechanical equipment, while it penalizes domestic hydromechanical fabricators by levying additional taxes and VAT on the raw inputs i.e. the metal sheets imported for fabrication.

(5) With the recent adoption of federal structure of Nepal and subsequent division of power between the Federal and regional governments, the coordination between regional governments and intersectoral ministries could pose as significant challenges in Nepal that could also threaten the success of HDP-2001 objectives. For instance, conflicting jurisdiction over river basins and divergence in environmental guidelines on shared rivers could create confusions.

\section{Conclusion}

Nepal's population growth, economic development, and urbanization is bound to increase its demand for electricity as well as diversification of electricity use from traditional lighting to heating, cooking, and transportation applications. Hydropower is the main source of Nepal's electricity supply, and it remains as Nepal's comparative advantage that can also help its low carbon transition. Therefore, a sound hydroelectricity policy ought to not only address the present outstanding challenges but also anticipate the future circumstances. The process of policy-design and its effective implementation in Nepal remains a challenge, and its success is often dictated by geographical, political, social, and economic conditions. In due consideration of these factors, the HDP-2001 has been successful in overcoming some of the pertinent challenges faced by the Nepalese hydroelectric industry, and hence the HDP-2001 can be considered as a reasonable hydroelectricity policy. Nonetheless, the unified policy also faces several limitations on account 
Birendra Rana, Adv. J Social Sci.; Vol. 7, Issue 1, pp: 71-80, 2020

of climate change, external economic shocks, effective monitoring mechanism, ensuring competitiveness, delivering fair price to the consumers, and a disproportionately high reliance on other sectoral policies. Designing practical mitigation plan, while being aware of its limitations, could be helpful in minimizing the impact of these exogenous factors.

\section{Competing Interests}

The author declared that no conflict of interest exists.

\section{How to Cite this Article:}

Birendra Rana. (2020). A SWOT Analysis of Nepalese Hydropower Policy. Advanced Journal of Social Science, 7 (1), 71-80. https://doi.org/10.21467/ajss.7.1.71-80

\section{References}

Alam, F., Alam, Q., Reza, S., Khurshid-ul-Alam, S., Saleque, K., \& Chowdhury, H. (2017). A Review of Hydropower Projects in Nepal. Energy Procedia, 110, 581-585. Retrieved 7 3, 2020, from https://sciencedirect.com/science/article/pii/s1876610217302187

Agyekum, E. B., Ansah, M. N. S., \& Afornu, K. B. (2020). Nuclear energy for sustainable development: SWOT analysis on Ghana's nuclear agenda. Energy Reports, 6, 107-115.

Ansar, A., Flyvbjerg, B., Budzier, A., \& Lunn, D. (2014). Should We Build More Large Dams? The Actual Costs of Hydropower Megaproject Development. Energy Policy, 69, 43-56. Retrieved 7 3, 2020, from https://sciencedirect.com/science/article/pii/s0301421513010926

Asian Development Bank. (2016). Basic Statistics. Manila: ADB.

Balasubramanya, S., Giordano, M., Wichelns, D., \& Sherpa, T. (2014). Sharing hydropower revenues in Nepal, over time and across districts and regions. Water Resources and Rural Development, 4(4), 104-111. Retrieved 7 3, 2020, from https://cgspace.cgiar.org/handle/10568/51635

Carvajal, P. E., Anandarajah, G., Mulugetta, Y., \& Dessens, O. (2017). Assessing uncertainty of climate change impacts on long-term hydropower generation using the CMIP5 ensemble-the case of Ecuador. Climatic Change, 144(4), 611-624. Retrieved 7 11, 2020, from https://link.springer.com/article/10.1007/s10584-017-2055-4

Central Bureau of Statistics. (2015, November 24). Nepal in Numbers. Kathmandu: Government of Nepal.

Chen, W. M., Kim, H., \& Yamaguchi, H. (2014). Renewable energy in eastern Asia: Renewable energy policy review and comparative SWOT analysis for promoting renewable energy in Japan, South Korea, and Taiwan. Energy Policy, 74, 319-329.

European Commission. (2004). National sustainable development strategies in the European Union: a first analysis by the European Commission,.

Fertel, C., Bahn, O., Vaillancourt, K., \& Waaub, J. P. (2013). Canadian energy and climate policies: A SWOT analysis in search of federal/provincial coherence. Energy Policy, 63, 1139-1150.

Fujikura, R., \& Nakayama, M. (2009). Lessons learned from the World Commission on Dams. International Environmental Agreementspolitics Law and Economics, 9(2), 173-190. Retrieved 7 3, 2020, from https://link.springer.com/article/10.1007/s10784-009-9093-y

Gc, A., \& Ghimire, K. (2018). A SWOT Analysis of Nepalese Agricultural Policy. Retrieved 7 3, 2020, from https://dergipark.org.tr/tr/download/article-file/534078

Gunatilake, H., Wijayatunga, P., \& Roland-Holst, D. (2020). Hydropower development and economic growth in Nepal. Asian Development Bank.

Halisçelik, E., \& Soytaş, M. A. (2019). Sustainable development from millennium 2015 to Sustainable Development Goals 2030. Sustainable Development, 27(4), 545-572. Retrieved 7 6, 2020, from https://onlinelibrary.wiley.com/doi/10.1002/sd.1921

Haque, H. E., Dhakal, S., \& Mostafa, S. (2019). An assessment of opportunities and challenges for cross-border electricity trade for Bangladesh using SWOT-AHP approach. Energy Policy, 111118. Retrieved 7 11, 2020, from https://sciencedirect.com/science/article/pii/s0301421519307050

Helms, M. M., \& Nixon, J. C. (2010). Exploring SWOT analysis - where are we now? Journal of Strategy and Management, 3(3), $215-251$. Retrieved 73 , 2020, from https://emerald.com/insight/content/doi/10.1108/17554251011064837/full/html

Igliński, B., Piechota, G., Iglińska, A., Cichosz, M., \& Buczkowski, R. (2016). The study on the SWOT analysis of renewable energy sector on the example of the Pomorskie Voivodeship (Poland). Clean Technologies and Environmental Policy, 18(1), 45-61. Retrieved 7 3, 2020, from https://link.springer.com/article/10.1007/s10098-015-0989-7

International Hydropower Association. (2020). Hydropower status report. International Hydropower Association: London, UK.

Irfan, M., Suleman, A. H., Sarwar, U. B., Abas, N., \& Saleem, M. S. (2019). SWOT analysis of energy policy 2013 of Pakistan. European Journal of Engineering Science and Technology, 2(1), 71-94.

Kaphle, R. R. (2019). Relationship between Remittance and Economic Growth in Nepal. Tribhuvan University Journal, 32(2), 249-266. Retrieved 7 11, 2020, from https://nepjol.info/index.php/tuj/article/view/24722

Kibler, K. M., \& Tullos, D. (2013). Cumulative biophysical impact of small and large hydropower development in Nu River, China. Water Resources Research, 49(6), 3104-3118. Retrieved 711, 2020, from https://agupubs.onlinelibrary.wiley.com/doi/full/10.1002/wrcr.20243

Lange, K., Meier, P., Trautwein, C., Schmid, M., Robinson, C. T., Robinson, C. T., . . Brodersen, J. (2018). Basin-scale effects of small hydropower on biodiversity dynamics. Frontiers in Ecology and the Environment, 16(7), 397-404. Retrieved 7 11, 2020, from https://esajournals.onlinelibrary.wiley.com/doi/abs/10.1002/fee.1823

Nepal Electricity Authority. (2019). Retrieved 7 3, 2020, from http://www.nea.org.np/annual_report 
A SWOT Analysis of Nepalese Hydropower Policy

Nepal, R., \& Paija, N. (2019). Energy security, electricity, population and economic growth: the case of a developing South Asian resourcerich economy. Energy Policy, 132, 771-781. Retrieved 7 6, 2020, from https://data.mendeley.com/datasets/np92pry38b/1

Neupane, A. (2014). The Necessity of/and Challenges to International Project Financing of Hydropower Projects in Nepal. Hydro Nepal: Journal of Water, Energy and Environment, 13, 16-19. Retrieved 7 3, 2020, from https://nepjol.info/index.php/hn/article/view/10033

Pachauri, S. (2014). Energy access, poverty, and development: the governance of small-scale renewable energy in developing Asia | Energy access, poverty, and development: the governance of small-scale renewable energy in developing Asia, Benjamin K. Sovacool, Ira Martina Drupady (2012). Energy, 68, 1007-1008. Retrieved 7 6, 2020, from https://sciencedirect.com/science/article/pii/s0360544214002187

Pathak, M. (2011). Climate change: uncertainty for hydropower development in Nepal. Hydro Nepal: Journal of Water, Energy and Environment, 6, 31-34. Retrieved 7 3, 2020, from https://nepjol.info/index.php/hn/article/download/4190/3564

Poudyal, R., Loskot, P., Nepal, R., Parajuli, R., \& Khadka, S. K. (2019). Mitigating the current energy crisis in Nepal with renewable energy sources. Renewable and Sustainable Energy Reviews, 116, 109388.

Proposal for Sustainable Development Goals .. Sustainable Development Knowledge Platform. (n.d.). Retrieved 7 3, 2020, from Sustainable Development Knowledge Platform: http://sustainabledevelopment.un.org/focussdgs.html

Pulice, S. M. P., Branco, E. A., Gallardo, A. L. C. F., Roquetti, D. R., \& Moretto, E. M. (2019). Evaluating monetary-based benefit-sharing as a mechanism to improve local human development and its importance for impact assessment of hydropower plants in Brazil. Journal of Environmental Assessment Policy and Management, 21(01), 1950003.

Rai, R. K., Bhatta, L. D., Dahal, B., Rai, B. S., \& Wahid, S. M. (2019). Determining community preferences to manage conflicts in small hydropower projects in Nepal. Sustainable Water Resources Management, 5(3), 1103-1114. Retrieved 7 3, 2020, from https://link.springer.com/article/10.1007/s40899-018-0285-x

Scolozzi, R., Schirpke, U., Morri, E., D'amato, D., \& Santolini, R. (2014). Ecosystem services-based SWOT analysis of protected areas for conservation strategies. Journal of Environmental Management, 146, 543-551. Retrieved 7 3, 2020, from https://sciencedirect.com/science/article/pii/s0301479714004241

Sen, A., Nepal, R., \& Jamasb, T. (2018). Have model, will reform: assessing the outcomes of electricity reforms in non-OECD Asia. The Energy Journal, 39(4), 181-209. Retrieved 7 6, 2020, from http://dro.dur.ac.uk/24193

Shakya, S., Nepal, R., \& Sharma, K. (2018). Electricity consumption and economic growth: empirical evidence from a resource-rich landlocked economy. International Journal of Global Energy Issues, 41, 226-247. Retrieved 7 3, 2020, from http://ecite.utas.edu.au/129844

Shem, C., Simsek, Y., Hutfilter, U. F., \& Urmee, T. (2019). Potentials and opportunities for low carbon energy transition in Vietnam: A policy analysis. Energy Policy, 134, 110818.

Shrestha, R. S., Biggs, S., Justice, S., \& Gurung, A. M. (2018). A Power Paradox: Growth of the Hydro Sector in Nepal. Hydro Nepal: Journal of Water, Energy and Environment, 23, 5-21. Retrieved 7 3, 2020, from https://nepjol.info/index.php/hn/article/view/20821/17098

Sovacool, B. K., Dhakal, S., Gippner, O., \& Bambawale, M. J. (2013). Peeling the Energy Pickle: Expert Perceptions on Overcoming Nepal's Electricity Crisis. South Asia-journal of South Asian Studies, 36(4), 496-519. Retrieved 7 6, 2020, from http://sro.sussex.ac.uk/id/eprint/58342

Suhardiman, D., \& Karki, E. (2019). Spatial politics and local alliances shaping Nepal hydropower. World Development, 122, 525-536. Retrieved 73,2020 , from https://sciencedirect.com/science/article/pii/s0305750x19301743

Sustainable Development Goals .. Sustainable Development Knowledge Platform. (n.d.). Retrieved 76 , 2020, from Division for Sustainable Development Goals, United Nations: http://sustainabledevelopment.un.org/?menu=1300

Timilsina, G. R. (2018). Regional electricity trade for hydropower development in South Asia. International Journal of Water Resources Development, 1-19. Retrieved 7 3, 2020, from https://tandfonline.com/doi/full/10.1080/07900627.2018.1515065

United Nations Millennium Development Goals. (n.d.). Retrieved 7 3, 2020, from United Nations: https://www.un.org/millenniumgoals/bkgd.shtml

Wang, C. (2012). A guide for local benefit sharing in hydropower projects. Retrieved 73, 2020, from https://openknowledge.worldbank.org/handle/10986/18366

Wang, X. (2017). Disclosable Version of the ISR - Nepal: Power Sector Reform and Sustainable Hydropower Development (PSRSHD) P150066 - Sequence No : 05. Retrieved 7 3, 2020, from http://documents.worldbank.org/curated/pt/563361514467942958/disclosable-version-of-the-isr-nepal-power-sector-reform-andsustainable-hydropower-development-psrshd-p150066-sequence-no-05

Worldometer (2020), Nepal Population (LIVE); https://www.worldometers.info/world-population/nepal-population/

Zhou, K. (2011). Himalayan Hydropower: Alternative Energy in Nepal. Harvard international review, 33(1), 8. Retrieved 7 3, 2020, from https://questia.com/library/journal/1g1-256711234/himalayan-hydropower-alternative-energy-in-nepal

Publish your research article in AIJR journals-

* Online Submission and Tracking

* Peer-Reviewed

* Rapid decision

* Immediate Publication after acceptance

- Articles freely available online

- Retain full copyright of your article.

Submit your article at journals.aijr.in
Publish your books with AIJR publisher-

* Publish with ISBN and DOI.

* Publish Thesis/Dissertation as Monograph.

* Publish Book Monograph.

* Publish Edited Volume/ Book.

* Publish Conference Proceedings

- Retain full copyright of your books.

Submit your manuscript at books.aijr.org 